\title{
ISIDORO DUCASSE, LECTOR DEL BARROCO ESPAÑOL
}

\author{
POR \\ EMIR RODRIGUEZ MONEGAL \\ Yale University
}

(Nació en Melo, Uruguay, el 28 de julio de 1921. Falleció en New Haven e1 14 de noviembre de 1985. Semanas antes de morir envió este artículo para que se publicara en la Revista Iberoamericana. Véanse en este número nota necrológica por Alfredo A. Roggiano y entrevista con Rita Guibert.)

\section{ISIDORE/ISIDORO *}

Es muy probable que Isidore Ducasse, falso Conde de Lautréamont, nunca haya usado la palabra barroco. Si la leyó, o empleó alguna vez, se-

* Un problema de nomenclatura se plantea siempre al referirse al autor de Les Chants de Maldoror. Su nombre legal es Isidore Lucien Ducasse. Pero al publicar en 1868 el primer Chant disimula la autoría detrás de tres discretos asteriscos. La obra completa saldrá en 1870 firmada por el Conde de Lautréamont, seudónimo que toma de una novela histórica de Eugène Sue sobre un personaje llamado Lautréamont. La versión de Ducasse es más eufónica y significativa; ha suscitado miles de interpretaciones: L'autre amont (La otra vertiente); L'autre [est] à Mont [evideo] (El otro está en M.), etc. En ambas versiones se sugiere el doble origen: montevideano y francés del poeta. Ya el último párrafo del primer Chant profetizaba la aparición de un poeta, «nacido en las orillas americanas, en la desembocadura del. Plata, allí donde dos pueblos que fueron rivales se esfuerzan hoy por superarse en el progreso material y moral. Buenos Aires, la reina del Sur, y Montevideo, la coqueta, tienden manos amigas sobre las aguas plateadas del gran estuario» (I, p. 92). La alusión a sí mismo es clara: Ducasse nació en Montevideo, 1846, durante la Guerra Grande, que dividió a la Argentina del Uruguay para siempre. Para su segundo y último libro, Ducasse utiliza su nombre legal: las Poésies se publican en 1870 como obra de Isidore Ducasse.

¿Por qué los asteriscos, el seudónimo, las máscaras? La explicación más simple es que, al publicar el primer Chant, él no quiso usar su nombre legal, que era el de su padre, de quien dependía económicamente. François Ducasse era un béarnés que, a pesar de llevar una vida privada bastante disipada en el Hôtel des Pyramides de Montevideo, preservaba una fachada de respetabilidad para justificar su cargo consular. Isidore no podía usar aquel nombre para un libro de escándalo. El seudónimo. de Lautréamont, en una de sus posibles lecturas, podria aludir a ese padre lejano y severo que estaba realmente en Montevideo. Con las Poésies, Ducasse asume la 
ría en el sentido habitual de su época (no hay que olvidar que murió en 1870); es decir: como el cuarto modo de la segunda figura en la nomenclatura escolástica del silogismo, según ha demostrado Benedetto Croce (Storia della Età barocca in Italia, 1929). Ya en 1519, Juan Luis Vives se burlaba de los profesores parisinos, que eran sofistas en baroco y en baralipton. El presidente de Brosses empleó el término en 1739 en el sentido de «extravagante, bizarro»; más generoso, Winckelman, en un trabajo de 1755 , lo usa para indicar lo decorativo, libremente juguetón de un estilo. Jakob Burckhardt, entre otros, lo aprovechó para definir la decadencia de la arquitectura florida de la Contrarreforma en Italia, Alemania y España, en un texto célebre de 1860.

¿Cuánta de esa información, hoy accesible a cualquiera a partir de los trabajos de René Wellek $(1945,1962)$, estaba a disposición de Isidore Ducasse? No se sabe. Sólo se sabe que el vocabulario de la crítica hispánica del período hablaba de conceptistas y culteranistas, del gongorismo, pero no del barroco. La palabra es usada sólo en 1886, y con una connotación negativa, por Menéndez Pelayo en Historia de las ideas estéticas en España, y no para referirse a Góngora o Quevedo, sino a un crítico portugués del siglo xviı. La crítica francesa fue aún más tardía en usar el término y todavía se resiste (en su mayoría) a aplicarlo a la literatura del Grand Siècle. Dados estos antecedentes, parece inútil hablar del barroco en el contexto de Isidore Ducasse, tal como ha sido definido por la erudición francesa ${ }^{1}$.

máscara del niño bueno que critica los excesos del romanticismo y abjura de su Maldoror. Puede firmar, pues, con el nombre legal. En este trabajo se identifica el autor como Isidore, si se trata de la obra literaria. Al concentrarme en esa lectura seminal de Hermosilla, en 1863, he preferido usar el Isidoro que él tan orgullosamente proclama en la inscripción de la traducción española de La Ilíada.

Las citas del texto están referidas a la accesible y precisa edición de Oeuvres complètes del primer Chant, del Maldoror completo y de los dos volúmenes de Poésies (39, 40, 355, 357, respectivamente). Fue publicada por Le Livre de Poche (París, 1963). Hay reediciones.

1. El trabajo de René Wellek está recogido en Concepts of Criticism (New Haven: Yale University Press, 1963) y se titula «The Concept of Baroque in Literary Scholarship», pp. 69-127. Marci Sternheim, del Departamento de Español, Yale University, prepara una tesis, bajo mi dirección, sobre el Barroco y Neobarroco, y la situación de la poesía de Sara de Ibáñez en este contexto. En la introducción estudia detenidamente el proceso de naturalización y metamorfosis del concepto en las letras hispánicas. Este trabajo coincide, en algunos aspectos, con el enfoque presentado allí, aunque difiere en otros. Para un examen general del barroco hispánico, véase Alfredo Roggiano, «Acerca de dos barrocos: el de España y el de América», en Memoria del XVII Congreso del Instituto Internacional de Literatura Iberoamericana (Madrid: Ediciones Cultura Hispánica, 1978), tomo I, pp. 39-47. 
$\mathrm{Y}$, sin embargo, hay pruebas de que Ducasse conoció, por lo menos, una obra en que la poesía hispánica del barroco era no sólo discutida acerbamente, sino citada con sin igual ferocidad. Me refiero al Arte de hablar (1826), de Josef Gómez de Hermosilla, la más famosa retórica española de su tiempo. Gracias a la publicación en 1977 de un mediocre libro sobre Le visage de Lautréamont, de Jacques Lefrère, se sabe que Ducasse era dueño de un ejemplar del Arte de hablar. Este hecho está documentado en la inscripción que el poeta dejó en un ejemplar de la traducción castellana de la Ilíada (1862), hecha por el mismo Hermosilla. Esa inscripción dice literalmente:

Propriedad [sic] del señor Isidoro Ducasse nacido en Montevideo (Uruguay).-Tengo tambiém [sic] «Arte de hablar» del mismo autor. 14 avril [sic] 1863 (Lefrère, 90) ${ }^{2}$.

Las faltas de español del texto no deben distraer al lector. Lo importante es que Isidore Ducasse se llame a sí mismo Isidoro; que escriba (mal o bien) en español; que reivindique la posesión del Arte de hablar. En un extenso trabajo, escrito en colaboración con la profesora Leyla Perrone-Moysés, y anticipado simultáneamente en español (Vuelta, Maldoror) y en francés (Poétique), hemos examinado en detalle las consecuencias de esta declaración, no sólo para la biografía del poeta, que aparece inscrito en un contexto cultural hispánico hasta ahora descuidado, y despreciado por los especialistas franceses, sino (muy particularmente) para su obra literaria, en la que tanto la lectura de Homero como el estudio de la retórica aparecen firmemente ligados a un crítico español de principios del siglo xIX. Lo que hoy quisiera examinar independientemente es un aspecto estudiado en escorzo en aquel trabajo: el de las posibles relaciones entre Lautréamont y el barroco hispánico. Esas relaciones, por hipotéticas que parezcan, abren infinitas posibilidades de interpretación de una de las obras más tantalizadoras de esta época ${ }^{3}$.

${ }^{2}$ El libro de Jacques Lefrère, Le visage de Lautréamont, fue publicado en París, por Pierre Horay, en 1977. Las ilustraciones que reproducen la inscripción de La Iliada están frente a la página 49. Como muchos estudios biográficos del poeta, éste está dedicado sobre todo al examen minucioso de sus aburridos contemporáneos, ya que la información factual sobre Isidore es mínima.

${ }^{3}$ Véase Leyla Perrone-Moysés/Emir Rodríguez Monegal, «Isidoro Ducasse et la rhétorique espagnole», en Poétique, 55, pp. 351-377, París, septiembre de 1983. Hay versión española en Vuelta, 79-80, México, junio de 1983 (4-14) y julio de 1983 (30-33). Estamos preparando actualmente una versión ampliada del texto para ser publicada en francés por la Éditions du Seuil, en su colección Poétique. El presente trabajo es una ampliación del capítulo correspondiente de ese libro. Es interesante notar que en Poésies, II, 364, Ducasse se burla del "gongorismo metafísico de los 


\section{UN DÓMINE IRACUNDO}

Hoy sólo los especialistas en el neoclasicismo hispánico practican las obras de Hermosilla. Mi contacto con ellas es casi milagroso. Se atravesaron en mi camino cuando estaba realizando una investigación sobre Andrés Bello y los orígenes del romanticismo hispanoamericano en el Museo Británico, de Londres, allá por 1950. Leí entonces, con tedio y risas, el Arte de hablar y el Juicio critico de los principales poetas españoles (1840), libros que Bello no sólo había estudiado, sino que había desmenuzado críticamente con lucidez y tino. En la obra en que recogí esta investigación (El otro Andrés Bello, 1969) quedan algunas trazas de mis lejanos contactos con Hermosilla ${ }^{4}$.

Declarar que la retórica y la crítica de este dómine hoy parecen irreparablemente obsoletas no es decir nada nuevo. Ya en el estudio de 1905, que precede a una reedición de $L a$ Ilíada, Menéndez Pelayo se había referido elocuentemente al temperamento apasionado, crítico y mordaz de Hermosilla y lo había calificado de «atrabiliario» ${ }^{5}$. La posición crítica de éste era doblemente anacrónica. En plena expansión romántica defendía los principios más rígidos del neoclasicismo, sin darse cuenta de que su tarea ya era inútil. Había elegido como blanco de su cólera el barroco y la poesía sentimental del siglo XVIII, en una hora en que ninguna de estas dos corrientes tenía vigencia alguna en la literatura hispánica y cuando la literatura viva se orientaba hacia el descubrimiento y definición de un romanticismo hispánico. La mera existencia de sus libros y el éxito de los mismos hasta bien entrado el siglo xIx (Ducasse los poseía en 1863) era la mejor demostración del divorcio total entre la literatura de los poetas y narradores más nuevos y la enseñanza de la literatura en los colegios y universidades. Como una estrella muerta, el neoclasicismo seguía iluminando las aulas hispánicas gracias a la devoción descabellada de dómines como Hermosilla. Era el Lukács del siglo xix: un reaccionario al servicio del oficialismo.

autoparodistas de mi tiempo barroco-burlesco», usando precisamente el término gongorismo en un sentido tradicional.

${ }^{4}$ El otro Andrés Bello (Caracas: Monte Avila, 1969) discute las opiniones, tan críticas, ciel autor venezolano sobre Hermosilla en los capítulos V (189-190, 219-224), VI $(268,318$ n.) y VII (401). Los textos pertinentes de Bello se encuentran en el tomo IX, Temas de crítica literaria, de la monumental edición de Obras completas, publicada en Caracas en 1956 bajo la supervisión de Pedro Grases. En su minucioso índice, Hermosilla aparece detallado en la página 758 .

s La Iliada (Madrid: Biblioteca Clásica, 1905), tres volúmenes. El estudio de Menéndez Pelayo está en el tercero. 
También Francia, y en particular en la clase de retórica del liceo de Pau, donde estudió Isidoro con el profesor Histin, a partir de 1864, se practicaba un discurso de tipo clasicista moderado. Pero en tanto que Hermosilla no se limitaba a defender el neoclasicismo, sino que cubría de injurias toda otra escuela, y en particular la gongorista, M. Histin era un retórico moderado y hasta amable. Por eso mismo, resultaba incomprensible hasta hace poco que Isidore Ducasse, o el Conde de Lautréamont, despotricase en forma tan virulenta contra los profesores de retórica y dedicase el destilado veneno de la prosa de sus Poésies (1870) a burlarse de la retórica al uso. Nada en $M$. Histin podía haber provocado esas burlas sangrientas, esas parodias vitriólicas ${ }^{6}$.

Pero si en lugar del amable y algo anodino $M$. Histin se coloca al iracundo y censorio Hermosilla, la reacción de Isidoro parece más justificable. No era contra la retórica que había aprendido Ducasse en Pau que escribía el perverso poeta. Era (es posible conjeturar) contra la que ilustraba en forma tan delirante ese Arte de hablar, cuyo orgulloso poseedor era el joven Isidoro Ducasse, uruguayo de Montevideo. Este cambio de perspectiva permite examinar en detalle las consecuencias críticas y poéticas de esa lectura y, en particular, pesquisar las trazas de un enfrentamiento con la poesía del barroco hispánico que la retórica de Hermosilla había permitido.

\section{EL BARROCO A CONTRAPELO}

Tanto en el Arte de hablar como en las Notas a su traducción de $L a$ Iliada (que tal vez Isidoro no conoció, ya que la edición que él poseía no llevaba notas), Hermosilla predica la lucidez, la frialdad y el control total de la razón, que eran atributos del neoclasicismo, al mismo tiempo que escribe con una virulencia y opina desde una posición tan «atrabiliaria» que su práctica desmiente su teoría. Por sus excesos retóricos, Hermosilla está de hecho más cerca del barroco (por lo menos el barroco de las polémicas entre Quevedo y Góngora) que del neoclasicismo. Ese ideal de precisión, litote y lucidez que él proclama, le es completamente inaccesible. Más cerca de su ideal se encuentra Gracián en su Agudeza y Arte de ingenio. Se ha dicho, para explicar esta contradicción, que el español es una lengua barroca. Garcilaso, Fray Luis, Bécquer, Alfonso Reyes, Jorge

${ }^{6}$ Sobre M. Histin, véase Lucienne Rochon, «Le professeur de rhétorique de Lautréamont: Gustave Histin», en Europe, 449, París, septiembre de 1966, y los comentarios al mismo en nuestro artículo de Poétique, pp. 370-371. 
Guillén y Borges bastarían para demostrar que el verso y la prosa hispánicos pueden prescindir de truculencias.

No interesa hoy abundar en las limitaciones de Hermosilla. Lo importante es registrar el hecho de que en las dos obras que estuvieron al alcance de Ducasse (una en el campo de la teoría, otra en el de la práctica), el joven montevideano de diecisiete años pudo conocer fragmentos de la poesía barroca que Hermosilla citaba con escarnio, o estuvo sometido a una versión homérica mucho más carnal y violenta que la practicada por las traducciones francesas de su época. Octavio Paz me dijo una vez que de muchacho había leído la versión de Hermosilla de La llíada y que le había impresionado mucho la intensidad de los pasajes eróticos. Esa intensidad está diluida, o escamoteada, en las versiones francesas ${ }^{7}$. Se puede conjeturar, creo, que a través de estas dos obras, Isidoro Ducasse tuvo acceso a una manera más robusta y hasta extravagante de escribir. Gracias a Hermosilla (y a contrapelo de la intención explícita del dómine español), el poeta entró en contacto con un código lingüístico que si no es inherente al español, marca una constante de la lengua y la literatura hispánicas ${ }^{8}$.

Conviene empezar el examen por la presentación negativa que hace Hermosilla del barroco hispánico en su Arte de hablar ${ }^{9}$. Allí condena buena parte de la práctica retórica del gongorismo, en que se resumen para él los horrores del barroco. Esa condena no se hace con argumentos, sino en una forma virulenta y autocrática. Al referirse, por ejemplo, a un poema del período, llegará a decir: «Para mí esto es jerigonza, y creo que lo

${ }^{7}$ Paz conserva todavía en su biblioteca, como una reliquia, la traducción de $L a$ Ilíada por Hermosilla. Sobre la posible influencia de esta traducción en Les Chants, véase el artículo citado de Poétique, pp. 357-359.

${ }^{8}$ En la versión original inglesa de The Classical Tradition, de Gilbert Highet (Oxford: Oxford University Press, 1949, pp. 110-111), se afirma: «The Spaniard, who love extremes, went further than either English or French in adopting not only Greek and Latin words but Greek and Latin syntactical patterns which could not really be naturalized, and in authors like Góngora distorted both language and thought.» En la versión al español de Antonio Alatorre, La tradición clásica (México: Fondo de Cultura Económica, 1949), y con anuencia de Highet (n. 9, p. 175), se ha rectificado este erróneo aserto. Ahora el texto revisado por Alatorre afirma: «Góngora llevó a la cumbre la tendencia aristocrática de Herrera. Sus innovaciones fueron objeto de reñidas polémicas, pero casi todas sobrevivieron. Los excesos de los poetas cultos quedaron refrenados por la tendencia casticista, siempre vigorosa, y cayeron muy pronto en el olvido los inútiles y pedantes cultismos introducidos por los malos gongorinos...» (I, pp. 175-178).

${ }^{9}$ Utilizo la edición del Arte de hablar en prosa y verso, editada y anotada por Vicente Salvá (Paris: Garnier, 1853-56), que fue probablemente la usada por Ducasse. Será designada en el texto por la sigla $A H$. 
será para todos. Mas no es Lope el único que así deliraba; lo mismo hacían los demás de sus contemporáneos, y los que le sucedieron» $(A H, 62)$. Hoy puede sorprender esta referencia a Lope como poeta delirante y gongorista, ya que es bien conocida la enemistad entre ambos vates, pero para Hermosilla estas distinciones no importaban. Sólo parece haber leído el Lope más barroco.

Con la misma violencia dogmática se burla de una metáfora de Rioja, quien tuvo la ocurrencia de llamar al mar "pesadumbre líquida» ( $A H$, 358), lo que resulta intolerable para el racionalismo del dómine. También habrá de atacar a Bernardo de Balbuena, cuya obra sirvió de puente temprano entre España y la América hispánica. Le reprocha uno de sus pasajes más hermosos:

Entre la tierra, el cielo, el mar y el viento

Un soberbio castillo está labrado;

Que aunque de huecos aires su cimiento

Y en frágiles palabras amasado,

Basa no tiene de mayor asiento

El mundo, ni los cielos se le han dado;

Pues sólo a él y su muralla fuerte

No ha podido escalar ni entrar la muerte $(A H, 45)$.

Estos impecables versos le merecen el sarcasmo de una interrogación racionalista: «¿Qué sitio era éste? ¿Serán los espacios imaginarios (...) los más disparatados sueños de un enfermo, (...) la imaginación más delirante?» (idem).

En su demolición, Hermosilla condena también inapelablemente el uso habitual por parte de los poetas barrocos de términos técnicos, tomados del vocabulario de las ciencias exactas o de las artes (geometría, astronomía, náutica). Su conclusión es drástica: «Es claro que no se deben usar sino cuando se hable con los profesores de la facultad a que pertenecen, porque los demás no les entenderán, o al menos no tienen obligación de entenderlos» $(A H, 148)$. La tirada se aplica a unos versos del mismo Balbuena que Hermosilla cita con furor:

Allí estrellas labró, allí movimientos, Cielos, luces, planetas, conjunciones, Signos, centros, epiciclos, detrimentos, Puntas, gozos, caída, exaltaciones, Casas, orbes, apogios, decrementos, Solsticios, cursos, vueltas, estaciones, Aspectos, rayos, auges, deferentes, Climas, ruedas, esferas, y ascendientes $(A H, 172)$. 
En su Arte de hablar, habrá de insistir en escoger, dentro de la vasta y variadísima obra de Lope de Vega, ejemplos de un uso excesivo del lenguaje técnico de la astronomía para confirmar así sus condenaciones. La belleza de los mismos pasajes que cita con irrisión, se le escapa por completo. Véase éste de Circe, como muestra de su ceguera y obstinación críticas:

No le recibe en nítido palacio

Dorado signo que humillando el vuelo

Nueva eclíptica forma, nuevo espacio

Entre los peces de la mar y el cielo (...)

Un monte que pirámide elevado

E1 rostro de la luna determina

Verde gigante al sol, bañado en plata,

De sus eclipses el dragón retrata $(A H, 16)$.

Otro pasaje del mismo Lope es elegido para la burla:

Las puertas adornadas de festones,

De istríadas columnas y de lazos,

Frisos, tríglifos, ménsulas, cartones,

Acroterias, metopas y cimazos,

De oro y estuco piñas y artesones

Frontispicios y bellos lagrimazos;

Y en las bóvedas y altos lacunarios,

Varios florones y mosaicos varios $(A H, 17)$.

¿Qué hubiera escrito Hermosilla de haber podido leer $E l$ acoso, de Alejo Carpentier, que no perdona una sola de las cornisas de la vieja Habana? Seguramente que habría despotricado contra los excesos técnicos del narrador cubano con una virulencia que falta en el pastiche delicioso de Guillermo Cabrera Infante (Tres tristes tigres, 1967) o en el no menos ingenioso travestismo de Severo Sarduy en Gestos (1963). La diferencia entre estos parodistas contemporáneos y Hermosilla es que el dómine español escribía con toda la seriedad del mundo. Esto lo hace aún más involuntariamente cómico.

Si Balbuena y Lope de Vega sólo eran para él objeto de escarnio, ¿qué habría escrito en su Arte de hablar sobre este pasaje de Lautréamont: «E1 magnetismo y el cloroformo, cuando se toman el trabajo, saben algunas veces engendrar de modo semejante esas catalepsias letárgicas» (C IV, 6)? ¿Cómo habría encarado este otro: «hermoso como la ley de la detención del desarrollo del pecho en los adultos cuya propensión al crecimiento no está de acuerdo con la cantidad de moléculas que su organismo asimila» (C V, 2)? Hermosilla habría considerado a Isidore Ducasse como un 
"energúmeno» que no sólo incurre en el vicio de usar un lenguaje técnico cuando no se está dirigiendo «a los profesores de las facultades», sino que agrava su error con una prosa más «disparatada» y «delirante» que el verso de Balbuena.

Pero lo importante no son las opiniones ni los excesos críticos de Hermosilla. Lo que cuenta para su lector, el joven montevideano Isidoro Ducasse, es que, al atacar el barroco y en particular a Balbuena y a Lope de Vega, Hermosilla cita abundantemente a estos poetas. Estas citas deben haber constituido una provocación irresistible. Eran, para él, la iniciación a una poesía de metáforas deslumbrantes, una poesía que no se cansaba de jugar con las palabras hasta extraerles sus lúdicos secretos, una poesía que explotaba los tropos hasta el delirio. Es decir: una poesía como la que estaba a punto de escribir, en esas vísperas de 1863, el inédito poeta suramericano.

En los ejemplos ferozmente condenados por Hermosilla (pero aun así copiosamente citados), Isidoro pudo encontrar las municiones que necesitaba para su demolición de la sintaxis francesa, para la parodización violenta de los modelos románíicos de su tiempo (y en particular de Hugo y la novela «gótica»), para la subversión total de una retórica que, vista desde su extrema marginalidad de montevideano bilinguie, sólo podía parecerle definitivamente arruinada. Por eso muchas de las irregularidades y extrañezas estilísticas de su obra, señaladas con retintín pedagógico por cierta crítica francesa y con sarcasmo racista por Robert Faurisson («comparaciones bufonescas», "perífrasis ampulosas», etc., dirá este involuntario discípulo de Hermosilla); todo lo que hace de la escritura de Lautréamont una escritura «extranjera» y «extraña» parecen casi moderadas si se las inserta en el contexto del barroco hispánico (A-t'on lu Lautréamont, Paris, Gallimard, 1972). Así, por ejemplo, se ha subrayado que Lautréamont abusaba de las personificaciones, a veces aplicadas a las partes del cuerpo («mis diez dedos concentrarán la totalidad de su atención»; «la advertencia solemne de mis sobacos», etc.) o referidas a las facultades psíquicas o morales («muchas conciencias enrojecieron»). También se ha subrayado que lograba efectos chocantes por medio de metáforas encadenadas. Ahora bien, en el manual de Hermosilla se encuentran ejemplos como éste, de Rioja:

El corazón entero y generoso

Al caso adverso inclinará la frente, Antes que la rodilla al poderoso $(A H, 363)$.

Ese corazón capaz de inclinar la frente y arrodillarse parece un caso extremo de lo que Hermosilla considera «disparate». Pero en el contexto 
de un lector que escribiría poco más tarde el primero de Les Chants de Maldoror, tal exageración resultaría normal.

Hoy nos puede parecer paradójico que Isidoro Ducasse haya encontrado en el más rancio neoclásico, el más anacrónico de los retóricos del siglo XIX, un estimulante para su proyecto poético de cretinización del lector (Poésies, II). Es precisamente ese anacronismo retrospectivo del dómine español, que elogia desmesuradamente el clasicismo cuando el romanticismo ya ha triunfado en casi toda Europa (la reaccionaria Francia está a punto de rendirse cuando se publica el Arte de hablar, a sólo cuatro años del estreno de Hernani), el que habrá de producir otro anacronismo, aún más violento, en el joven lector montevideano. Es un anacronismo que se podría calificar de "prospectivo», porque a través de su lectura paródica y a contrapelo del Arte de hablar, Isidoro Ducasse llegará a formular, bajo la máscara del Conde de Lautréamont, la crítica más feroz del romanticismo. Esa crítica parece inspirarse en las teorías retóricas de la pedagogía francesa del siglo XIx, pero está realmente enraizada en la carnavalización de los principios de Hermosilla. Será precisamente en su último libro, paradójicamente llamado Poésies y escrito en prosa, en donde Isidoro, asumiendo ya su nombre legal de Isidore Ducasse, entierra el romanticismo e inatugura teóricamente una literatura del porvenir que los surrealistas, con Breton a la cabeza, fueron los primeros en (re)descubrir. Esos dos libros producidos por el joven montevideano, desubicados e inubicables en su siglo, encontrarían su querencia en el nuestro.

Debido a este tal vez involuntario aprendizaje del barroco español que le permitió la lectura del Arte de hablar, Lautréamont/Ducasse pudo articular mejor una crítica del romanticismo ya triunfante en Francia. Esa crítica se manifiesta en la exasperación hiperbólica de los cinco primeros cantos de Maldoror, que lleva los excesos retóricos y la pomposidad cósmica de un Víctor Hugo (la oda al mar en el canto primero, por ejemplo) al terreno de la parodia más violenta, así como a la síntesis violenta de la novela gótica a lo Eugène Sue (y también, hélas, de Les misérables), que ocupa tanto el canto sexto. Esa misma crítica aparece explícita en la condenación vitriólica de algunos textos canónicos franceses que practican perversamente los fragmentos titulados Poésies. Allí, la parodia es tan explícita que no ha escapado ni a los críticos más rutinarios del poeta ${ }^{10}$.

${ }^{10}$ La crítica ha prestado, en general, escasa atención a la parodia, teórica y práctica, de la novela folletinesca a lo Eugène Sue en que consiste, explícitamente, el canto sexto de Maldoror. Un libro reciente, y muy perspicaz, de Peter Brooks, Reading for the Plot (New York: Vintage Books, 1985), que se ocupa precisamente, como dice el subtítulo, del «Design and Intention in Narrative», no menciona siquiera a Maldoror. Es cierto que las referencias a Sue, muy escasas, tampoco parecen 
Para Isidore Ducasse era evidente el parentesco entre aquel barroco. hispánico execrado por Hermosilla y el romanticismo victorioso de su. época. La vinculación Gótico-Barroco-Romanticismo es hoy uno de los lugares comunes de la crítica. Se remonta a observaciones, más o menos. lúdicas, de Eugenio d'Ors, que es posible excavar de sus escritos de los años veinte y treinta de este siglo. Así, por ejemplo, en un ensayo recogido en Las ideas y las formas (1928), el crítico catalán se había referido al romanticismo como un movimiento barroco. Más tarde, al ampliar y poner al día sus ideas para un libro francés, Du Baroque (1935), d'Ors llegaría a precisar:

Le Baroque est une constante historique qui se retrouve à des époques aussi réciproquement éloignées que l'Alexandrisme de la ContreRéforme ou celle-ci de la période «Fin de siècle», c'est-à-dire de la fin $\mathrm{du} \mathrm{xIX}^{\mathrm{e}}$ et qu'il s'est manifesté dans les régions les plus diverses, tant en Orient qu'en Occident. (...) Loin de procéder du style classique, le Baroque y est opposé d'une manière plus fondamentale encore que le romantisme qui, lui, n'est en somme qu'un épisode dans le déroulement de la constante baroque ${ }^{11}$.

Este punto de vista es tan radical que termina por diluir todo concepto del barroco; sin embargo, lo que es interesante en su formulación, y lo que indudablemente ha influido en la crítica posterior, es esa categorización del barroco como forma heterodoxa. Antes de d'Ors, y con un poco más de cautela, la crítica de arte y cultura alemana de fines del siglo XIX

reflejar una lectura directa de Les mystères de Paris. Esta novela, sin embargo, así como su complemento, Le Juif errant, son modelos del plot en el sentido que inquiere Brooks.

${ }^{11}$ Du Baroque (Paris: Gallimard, 1935, pp. 100-101). La versión española del libro de D'Ors es muy tardía: Lo barroco (Madrid: Aguilar, 1964). En la página 125,. y al pasar, D'Ors afirma, con su acostumbrada ligereza panorámica: «El Barocchus finisecularis [traducción al castellano: el barroco fin de siglo] es el de Wagner y el de Rodin, el de Rimbaud y el de Aubrey Beardsley, de Bergson y de William James, el de los arquitectos y decoradores cuya obra era entonces tomada como expresión del 'modernismo' o del 'decadentismo'. El barroco de Lautréamont y del novelesco Des Esseintes, el de aquellos peinados en bandós, el de aquellos carteles y aquellos ex-libris, el estilo vegetal de los arcos y parábola y de los vasos con orquídeas» (Paris, 170). Aparte de la exageración de asimilar todo estilo no clásico al barroco, D'Ors incurre en la ingenuidad de comparar al tigre de la selva, que es Maldoror, con el gato domesticado y perverso que es el personaje de $A$ rebours, de Huysmans. El ensayo fue presentado en una reunión del Congreso sobre Barroco en Pontigny, 1931. Véase Pierre Charpentrat, Le mirage baroque (Paris: Minuit, 1967, pp. 80-81). Un examen más detallado del texto de D'Ors aparece en Claude-Gilbert Dubois, Le Baroque (Paris: Larousse, 1973, p. 35). Es éste uno de los pocos libros franceses que no tiene una actitud nacionalista o patrocinadora hacia el barroco. 
y comienzos del xx había establecido algunos vínculos entre el barroco y el romanticismo. Me refiero, en particular, a trabajos de Spengler, Worringer y Walzel. Aunque esos intentos hayan sido criticados posteriormente por historiadores de la categoría de René Wellek, es indudable que había en ellos la semilla de una intuición valiosa ${ }^{12}$.

Que esa intuición haya sido anticipada, y de una manera explosiva, por el joven Isidoro en el Montevideo de 1863 no debe asombrar a nadie, sobre todo si se tiene en cuenta la provocación que debió de haber representado para él la lectura del Arte de hablar. Desde su posición de marginal y heterodoxo dentro de la rígida estructura de la cultura oficial francesa de la segunda mitad del siglo XIx, alienado por su bilingüismo de la pureza sintáctica que esa cultura promovía con tesón, Isidoro estaba en las mejores condiciones para detectar afinidades sutiles que aún no se habían convertido en lugares comunes de la crítica de su tiempo.

\section{EL BARROCO DE LOS MODERNISTAS}

Al situarse así, imaginariamente, entre el barroco y el romanticismo, Isidore Ducasse-Lautréamont pudo anticipar buena parte del trabajo crítico y poético que realizarían sobre el barroco los escritores hispánicos de fines del siglo XIX y comienzos del xx. Reaccionando contra la posición hermosillesca del escarnio que hereda en forma más erudita y bien educada Menéndez Pelayo, los poetas hispánicos que se agrupan bajo el nombre de Modernistas (y que equivalen a sus colegas del simbolismo francés o el luso-brasileño) efectuarán una revisión apasionada de Góngora, de Quevedo y de Gracián, entre otros. En esto, como en otras cosas, fueron precedidos por algunos pioneros franceses. Tanto en el terreno de la crítica literaria o de la erudición como en el de la poesía, el simbolismo estaba muy favorablemente dispuesto hacia Góngora. En tanto que R. Fouché Delbosc preparaba una edición crítica de su poesía y anticipaba en la Revue Hispanique los resultados de su pesquisa (ya hay un artículo en 1900: las poesías, en tres volúmenes, saldrán en 1921), Lucien Paul Thomas escribe en el Bulletin Hispanique de 1909 un artículo bibliográfico que será antecedente de su libro del mismo año sobre Le lyrisme et la préciosité cultistes en Espagne, y, sobre todo, del estudio fundamental de 1911: Góngora et le gongorisme considerées dans leur rapports avec le marinisme ${ }^{13}$.

${ }^{12}$ Véase Wellek, p. 91.

${ }^{13}$ Le Lyrisme fue publicado por Max Niemeyer (Halle, 1909); el libro sobre Góngora, Honoré Champion (Paris, 1911). 
Este último libro habrá de inspirar al más importante crítico del simbolismo francés, el sutil Rémy de Gourmont, un artículo de 1911 sobre «Góngora et le gongorisme», en el que, si bien se equivoca al resumir las tesis de Thomas (éste no encontraba vinculación alguna entre el marinismo y el gongorismo, contra lo que mal leyó Gourmont), adelanta un tantalizador paralelo entre Mallarmé y el poeta cordobés. Este artículo habrá de ser decisivo en la lectura de ambos poetas que ya había empezado a practicar el precoz Alfonso Reyes en sus primeros ensayos críticos ${ }^{14}$.

Pero quien sin duda lo leyó con más inmediata eficacia fue otro latinoamericano, más viejo y más famoso que el joven Reyes. Me refiero a Rubén Darío, que andaba por Europa en esos años crepusculares del siglo y que, en el París de 1893, ya recogió las señales de una revalorización de Góngora. Como él mismo ha contado en su parcial Autobiografía (capítulo 33), Jean Moréas fue uno de los poetas del momento con quien «tuve más intimidad» (p. 104) ${ }^{15}$; más adelante señala:

Me habían dicho que Moréas sabía español. No sabía ni una sola palabra. Ni él, ni Verlaine, aunque anunciaron ambos, en los primeros tiempos de la revista La Plume, que publicarían una traducción de $L a$ vida es sueño, de Calderón de la Barca (Obras, I, 105).

La idea de traducir a Calderón, aun con un total desconocimiento de la lengua española, indicaba ya una simpatía por el barroco hispánico que se confirma y amplía en el párrafo siguiente al hablar de Verlaine:

... solía pronunciar, con marcadísimo acento, estos versos de Góngora: «A batallas de amor campo de plumas»; Moréas, con su gran voz sonora, exclamaba: «No hay mal que por bien no venga...», y con el mismo tono, cuando divisaba a Gómez Carrillo, gritaba: «iDon Diego Hurtado de Mendoza!» Tanto Verlaine como Moréas eran popularísimos en el Quartier Latin, y andaban siempre rodeados de una corte de jóvenes poetas que, con el Pauvre Lélian [Verlaine], se aumentaban de gentes de mala bohemia, que no tenían nada que ver con el arte ni con la literatura (pp. 106-107).

En otro lugar de la Autobiografía completa Darío este cuadro del decadentismo con la descripción de un primer encuentro con Verlaine:

${ }^{14}$ El artículo de Gourmont está recogido en la cuarta serie de las Promenades littéraires (Paris: Mercure de France, 1911, pp. 299-310), que está dedicada sobre todo a la evocación personal del simbolismo por parte del agudo crítico francés.

${ }^{15}$ Cito por la edición de Obras completas de Darío (I, 15-177), publicada en Madrid en 1950 por Afrodisio Aguado, S. A. (jqué nombre, ay!). 
Uno de mis grandes deseos era poder hablar con Verlaine. Cierta noche, en el café D'Harcourt, encontramos al Fauno, rodeado de equívocos acólitos. Estaba igual al simulacro en que ha perpetuado su figura. el arte maravilloso de Carrière. Se conocía que había bebido harto. Respondía, de cuando en cuando, a las preguntas que le hacían sus acompañantes, golpeando intermitentemente el mármol de la mesa. Nos acercamos con Alejandro Sawa; me presentó: «Poeta americano admirador, etc.» Yo murmuré en mal francés toda la devoción que me fue posible y concluí con la palabra gloria... Quién sabe qué habría pasado. esta tarde al desventurado maestro; el caso es que, volviéndose a mí, y sin cesar de golpear la mesa, me dijo en voz baja y pectoral: iLa gloire!... iLa gloire!... M... M... encore!... Creí prudente retirarme y esperar para verle de nuevo en una ocasión más propicia. Esto no lo pude lograr nunca, porque las noches que volví a encontrarle se hallaba más - menos en el mismo estado y aquello, en verdad, era triste, doloroso, grotesco y trágico. iPobre Pauvre Lelian! iPriez pour le pauvre Gaspard!... (cap. 32, 103-104).

La última cita en francés pertenece, sin duda, a una época posterior en que Dario aprendió un poco más de francés. Pero en el momento del histórico encuentro con Verlaine, el diálogo fue de sordos, en más de un sentido. En primer lugar, porque la heterosexualidad elemental de Darío. se sintió atacada por esa corte de jóvenes poetas homosexuales que él califica, obviamente, de «equívocos acólitos». En segundo lugar, porque la ignorancia del francés impide a Darío decir algo más que unas frases convencionales, que Verlaine aniquila con la irrisión de su iMerde... merde encore!, que Darío transcribe con púdicos puntos suspensivos para no ofender a los cultos lectores de Caras y Caretas, de Buenos Aires, en donde se publicó por primera vez esta Autobiografía (1912). Lo más importante, sin embargo, de este recuento es que permite conjeturar que Darío nunca oyó a Verlaine recitar a Góngora y que la descripción ya citada del capítulo 33 se apoya tal vez en el testimonio del propio Moréas.

Para la historia literaria lo que cuenta, sin embargo, es que en su primer viaje al París de 1893, Darío haya oído a Moréas, y tal vez al propio Verlaine, cantar loas a Góngora. Será a partir de esos encuentros que éste y otros escritores barrocos entrarán en el panteón del poeta nicaragiense. Por eso, en las «Palabras liminares» de Prosas profanas (1896) podrá escribir esta adhesión irrestricta al barroco:

El abuelo español de barba blanca me señala una serie de retratos ilustres: «Este - me dice- es el gran don Miguel de Cervantes Saave-

${ }^{16}$ Obras completas (I, 193-224). 
dra, genio y manco; éste es Lope de Vega, éste Garcilaso, éste Quintana.» Yo le pregunto por el noble Gracián, por Teresa la Santa, por el bravo Góngora y el más fuerte de todos, Don Francisco de Quevedo y Villegas. Después exclamo: «iShakespeare! ¡Hugo!...» Y en mi interior: iVerlaine! (p. 546).

Años antes, al escribir la Historia de mis libros (1909), Darío se había referido ya con orgullo al impacto que tuvieron en España estas «Palabras liminares»:

En cuanto a la cuestión ideológica y verbal, proclamé ante glorias españolas más sonoras, la del gran D. Francisco de Quevedo, de Santa Teresa, de Gracián, opinión que más tarde aprobarían y sostendrían en la península egregios ingenios (Obras, I, 206).

Es curiosa la omisión del «bravo Góngora», tal como lo había calificado en las «Palabras liminares» en Prosas profanas, pero aun con esta omisión resulta evidente que Darío sabía muy bien la importancia de su revaloración de ciertos escritores del barroco que la crítica más tradicional había menospreciado. En este mismo contexto debe destacarse el artículo de extravagante elogio que Darío dedicó al Conde de Lautréamont en sus Raros (1896). Ya se ha probado que ese artículo es, en buena parte, transcripción, si no plagio, de uno anterior de Léon Bloy (1890). Este aspecto es secundario; lo importante es que al hacer suyas las palabras de Bloy, Darío rendía el homenaje del asombro a la obra entonces casi desconocida del poeta montevideano. El artículo empieza documentando la escasez de una información segura sobre este autor: «Su nombre verdadero se ignora.» También sostiene que «murió loco». De inmediato informa: «Léon Bloy fue el verdadero descubridor del conde de Lautréamont. Hoy mismo, en Francia y Bélgica, fuera de un reducidísimo grupo de iniciados, nadie conoce ese poema que se llama Cantos de Maldoror, en el cual está vaciada la pavorosa angustia del infeliz y sublime montevideano, cuya obra me tocó hacer conocer a América en Montevideo» (Obras, II, 435) ${ }^{17}$.

Parece que entonces Darío no había leído directamente a Lautréamont, como ha demostrado fehacientemente Publio González Rodas ${ }^{18}$. Todas las citas de la obra del montevideano coinciden con las del artículo de Bloy. Hasta la más famosa del encuentro fortuito del paraguas y la máquina de coser sobre la benemérita mesa de disección (que deslumbraría a Breton) ya aparece en Bloy antes de ser usada en los Raros. La última referencia

${ }^{17}$ Obras completas (II).

${ }_{18}$ Publio González Rodas, «Rubén Darío y el Conde de Lautréamont», en Revista Iberoamericana (Pittsburgh, núm. 75, abril-junio 1977), pp. 375-389. 
del texto de Darío sobre su cualidad de pionero, al hacer conocer al poeta montevideano en su propia patria, no es comentada por González Rodas. Darío se refiere implícitamente a una conferencia del 11 de julio de 1912, sobre Julio Herrera y Reissig, que dictó en el Teatro Solís de Montevideo, y en la que se refirió al precursor Maldoror ${ }^{19}$. De esta manera (tal vez sin advertirlo) enlazaba a dos poetas malditos: el delirante jovencito de mil ochocientos sesenta y tantos y el no menos delirante joven maduro del novecientos: el uno, en su anacronismo prospectivo, que lo hacía proyectarse del barroco a la vanguardia por el camino de una demolición de la retórica romántica; el otro, que saltaba del modernismo a la vanguardia por la parodización extrema de los modelos de su tiempo ${ }^{20}$.

\section{LA DOBLE RESURRECCIÓN}

Otro lector temprano de Góngora fue Alfonso Reyes, quien ya en Cuestiones estéticas (1911) había dedicado un estudio de finísima intuición a la «Estética de Góngora» (1910), en el que hay una cortés rectificación de las opiniones de Menéndez Pelayo. En el mismo volumen, un trabajo de 1910 «Sobre el procedimiento ideológico de Stéphane Mallarmé» muestra que Reyes estaba leyendo paralelamente a dos practicantes extremos de la metáfora, dos de los maestros que renovarían la poesía de vanguardia. El mismo año de 1911, en que salen las Cuestiones estéticas, ambos poetas serían vinculados por Rémy de Gourmont en un artículo ya citado. Lo que estas críticas de Reyes tienen de pioneras resulta enfatizado por el hecho de que el autor mexicano sólo tenía veintidós años cuando las recogió en libro. Más tarde, exiliado discretamente en España, Reyes continuaría sus investigaciones sobre el poeta cordobés y hasta ayudaría a Foulché-Delbosc en sus pesquisas. El fruto de ese trabajo aparecerá en el volumen erudito Cuestiones gongorinas (1927), que Reyes recoge en plena revalorización del poeta cordobés ${ }^{21}$.

Entre tanto, los mismos españoles estaban rectificando discretamente el rumbo. Uno de los más importantes trabajos de la época fue el docu-

19 Véase mi edición de las Obras completas de Rodó (Madrid: Aguilar, 1957; 2. ${ }^{\text {a }}$ edición, 1967, p. 1368) para el detalle de este episodio montevideano.

${ }^{20}$ Para una lectura vanguardista y paródica de Herrera y Reissig, véase mi trabajo «El caso Herrera y Reissig», en Eco, junio-agosto 1980, pp. 199-216. Por descuido de la redacción se anuncia como incompleto. No es así.

${ }^{21}$ Cuestiones gongorinas (Madrid: Espasa Calpe, 1927). Hay reedición accesible en las Obras completas de Reyes (México: Fondo de Cultura Económica, 1958, VII, pp. 10-167). Uno de los inesperados colaboradores del erudito mexicano en sus pesquisas gongorinas fue Martín Luis Guzmán. 
mentadísimo libro de Miguel Artigas, Don Luis de Góngora y Argote. Biografía y estudio crítico, premiado por la Real Academia Española y publicado en 1925 a expensas de esta tradicional institución. Con extrema delicadeza, Artigas examina la ceguera de la crítica decimonónica con respecto a Góngora y traza un discreto panorama del cambio de rumbo. Es indudable que no sólo su erudición, sino su tacto, favorecieron el ingreso de Góngora al cielo oficial de una institución dedicada a la limpieza, fijeza y esplendor de la lengua castellana. iAl fin el poeta cordobés había sido aceptado como cristiano viejo! ${ }^{22}$

Paralelamente a Miguel Artigas, los poetas de la generación del 27 estaban muy activos en su reivindicación del poeta cordobés. La publicación casi simultánea de volúmenes dedicados a su obra, para celebrar el tercer centenario de su muerte en 1927 , certifica ese cambio radical de perspectiva. Aparte de los estudios gongorinos de Reyes, se darán a estampa la Antología poética en honor de Góngora, recogida por el poeta. ultraísta Gerardo Diego, y cuyo último celebrante es precisamente Rubén Darío con el poema «Trébol», de Cantos de vida y esperanza (1905); y la prosificación de las Soledades por el poeta Dámaso Alonso, que sirvió para demostrar que si Góngora es un poeta hermético (y, por lo tanto, con clave o llave), no es un poeta ilegible. Ambos textos habían sido precedidos, en 1923, por una elegantísima y pulcra transcripción textual de la: Fábula de Polifemo y Galatea que había preparado Reyes para la exquisita Biblioteca de Indice, que dirigía Juan Ramón Jiménez ${ }^{23}$. El interés de Juan Ramón Jiménez por Góngora no era nuevo ni había esperado el pretexto del tercer centenario. Ya el primer número de su revista Helios (abril de 1903) inaugura una sección para recoger opiniones sobre don Luis, al que se presenta con estas palabras:

Góngora es para unos singular ingenio y ornamento el más preciado del Parnaso español, en tanto que otros lo tildan de estar tocado del deseo de hacerse cabeza de una nueva escuela, negocio que lo indujo a abrazar el estilo hueco, obscuro y fantástico. A los que seguimos más severas musas no nos es lícito ser tan extremosos. Que los que puedan opinar, opinen. Para ellos iniciamos esta sección. ¡Así al cerrarla podamos conocer a $\mathrm{D}$. Luis de Góngora, y cuánto de liviano y bello encierra su obra! (Reyes, p. 255).

${ }^{22}$ E1 libro fue publicado en Madrid en 1925, y en las páginas 250-254 se encuentra una documentada y discretísima reseña del cambio de estimativa sobre Góngora a partir de Menéndez Pelayo y hasta alcanzar los trabajos de Reyes y Gerardo Diego.

${ }_{23}$ La Antología poética de Diego fue publicada por Revista de Occidente (Madrid, 1927), que también publicó la edición de Dámaso Alonso de las Soledades el mismo año. La edición del Polifemo es de Madrid (Indice, 1923). 
Como se observa en las Cuestiones gongorinas (de donde tomo esta información), las respuestas — de Azorín, Unamuno, Navarro Ledesma y algún otro- ocupan sólo un total de diez páginas de la revista. Lo que no parece mucho hoy, pero era bastante en 1903.

E1 tercer centenario habría de consolidar definitivamente el puesto de Góngora como uno de los poetas centrales de la lengua. El valor de esta reivindicación y el papel de los poetas españoles de la generación del 27 ya ha sido suficientemente glosada por la crítica. Ahora quisiera apenas marcar la importancia de algunas opiniones de poetas hispanoamericanos que colaboraron con sus colegas peninsulares en esta revalorización. Las más famosas son de Jorge Luis Borges y Pablo Neruda. El primero inició su carrera literaria con los ultraístas sevillanos hacia 1920. Trasladado a Madrid en 1921, allí se unió a Gerardo Diego y a Guillermo de Torre para promover la causa vanguardista. Su participación principal en la revaloración del barroco fue un seminal ensayo sobre «Grandeza y menoscabo de Quevedo», que publicó la influyente Revista de Occidente (noviembre de 1924). También se adhirió Borges a los festejos del tercer centenario de Góngora con una nota publicada ya en Buenos Aires, en la que comenzaba afirmando provocativamente: "Yo siempre estaré listo a pensar en D. Luis de Góngora cada cien años.» En otros trabajos del período, recogidos en libros de crítica que el Borges maduro ha cancelado y son, por lo tanto, inhallables, hay más opiniones sobre Góngora y el barroco, con atinados comentarios sobre el arte narrativo de Cervantes, la crítica de Gracián y, sobre todo, la obra de Villarroel. Al pasar, hay también alguna flechita polémica contra ciertos excesos interpretativos de Dámaso Alonso en sus prosificaciones ${ }^{24}$.

La contribución de Neruda es más tardía. Llegaría a España en 1934, cuando el culto a Góngora y la reivindicación del barroco ya no eran temas polémicos. Pero por su práctica poética y por algunos trabajos sobre Quevedo y el Conde de Villamediana, Neruda suma la fuerza de su verbo a una causa que treinta años antes parecía tan frágil. Así, por caminos en que se funden y confunden las nuevas legiones poéticas peninsulares con las hispanoamericanas, el barroco recuperaría en el siglo xx el lugar de privilegio que le había correspondido en las letras hispánicas del Siglo de Oro, no sólo en la península, sino sobre todo en América, donde tuvo una sobrevida realmente original. Ese movimiento de revaloración coin-

${ }^{24}$ «Borges, lector del barroco español», en Revista de la Universidad de México (núm. 10, junio 1975, 25-32). Se acaba de publicar en Pisa (ETS, 1984) un volumen a cargo de Giulia Poggi y Pietro Taravacci, Le bugie della parola. Il giovane Borges $e$ il barocco, que recoge y traduce muchos de los textos fundamentales de Borges sobre el tema. Merece ser traducido al español. 
cide cronológicamente con el redescubrimiento de la obra de Isidore Ducasse por los surrealistas, tal como lo documenta el Primer Manifiesto de Breton (1924). Allí el poeta montevideano es presentado como el único y más alto ejemplo de poeta surrealista, y sus metáforas (tan oscuras para los hombres del siglo XIX) son elevadas a paradigmas de la vanguardia. La canonización definitiva del autor de Les Chants de Maldoror empieza allí. Esta obra, incómoda y anacrónica en su siglo, resulta ahora doblemente inscripta en la literatura de la vanguardia, y en particular de la rama hispánica. Por la influencia de los surrealistas, y a través del intuitivo Ramón Gómez de la Serna, Lautréamont llega a este mundo, linguíísticamente ajeno en apariencia. Pero también, y en forma más sutil y discreta, porque su arte de la metáfora revelará a ciertos lectores inesperadas vinculaciones con ese barroco que se está empezando a releer entonces. Por esa doble inscripción (surrealista, barroca), el texto de Lautréamont, aunque escrito en francés, se convierte en un texto hispánico seminal.

\section{LA LECTURA NEOBARROCA}

La historia de la posteridad de Lautréamont/Ducasse no concluye aquí. Entre los nuevos lectores que encontrará en la América hispánica hay por lo menos uno que será capaz de enlazar en su verso sin par la doble herencia de Góngora y Ducasse. Me refiero, es claro, al poeta cubano José Lezama Lima. En un crítico ensayo de su Analecta del reloj (1953), titulado «Sierpe de don Luis de Góngora», se practica una lectura radial del poeta, que va mucho más lejos que todo lo que se había realizado en España hasta la fecha. Por medio de metáforas herméticas y hasta ilegibles (por definición), Lezama Lima va sugiriendo una lectura dispersa e infinita de la vida y la obra del ingenio cordobés. Texto en prosa que usa el sistema metafórico del verso; barroco y ducassiano a la vez, inaugura la lectura del subtexto gongorino, con todas sus perversiones- y no sólo las retóricas-, que ilumina pasajes misteriosos e inexplicables del autor de las Soledades ${ }^{25}$. Más tarde, en unas conferencias relativamente más transparentes, que recogerá en La expresión americana (1957), Lezama relee al poeta cordobés, y al barroco entero, no a la luz limitada y limitante de la crítica peninsular, sino a la mucho más tardía, pero más compleja, de los grandes poetas barrocos americanos: Sor Juana Inés de 1a Cruz, de México, y Domínguez Camargo, de Colombia. En su lectura,

${ }^{25}$ Analecta del reloj (La Habana: Orígenes, 1953, pp. 183-214). Hay reedición accesible en Obras completas de Lezama Lima (México: Aguilar, 1977, II, pp. 183213). Citaré por esta edición de ahora en adelante. 
Lezama busca también apoyo en la obra heterodoxa del arquitecto indio Kondori y del arquitecto y escultor brasileño O Aleijandinho. Estas lecturas inauguran una nueva manera de leer el barroco hispánico ${ }^{26}$.

Paralelamente a esta reformulación del barroco, Lezama se sumerge en un estudio minucioso de la poesía francesa a partir de Baudelaire, lo que lo llevará, naturalmente, al surrealismo y al descubrimiento de Lautréamont. Aunque pocos críticos han siquiera tocado el tema (los más perspicaces: Julio Cortázar, Cintio Vitier, Armando Alvarez Bravo) ${ }^{27}$, es indudable que la lectura de Les Chants de Maldoror y la práctica de una suerte de escritura automática llevaron a Lezama a profundizar un sistema metafórico que terminaría por ser suyo. Las referencias directas a Lautréamont en sus escritos críticos son escasas y se concentran casi todas en trabajos de los años 1945 a 1953. Así, por ejemplo, en un ensayo de Orígenes (1945) sobre Cintio Vitier, «Después de lo raro, la extrañeza», hace una referencia irónica a los burgueses, «profesores raté [sic], disfrazados de Lautrémont [sic] o de Kafka», para burlarse de la domesticación pedagógica a que ha sido sometido el blasfemante Conde. (Inevitablemente Lezama incurre en dicha frase en un par de erratas que le hacen escribir mal no sólo el nombre del poeta, sino dejar en singular el adjetivo raté) ${ }^{28}$. Más importante que esta pulla son las referencias explícitas a Lautréamont en dos ensayos de Analecta del reloj. En uno sobre Garcilaso, y precisamente al discutir a Góngora, apunta:

Formado por el poeta el orbe poético es arrastrado por él: en ocasiones, como en el caso de Lautréamont, creerá romperlo, dominarlo, detenerlo cuando quiera $(O . C ., 17)^{29}$.

Esta vez (gracias a una mayor atención o a un sensato corrector de pruebas) el nombre aparece correctamente escrito. También es correcta la

${ }^{26}$ Obras completas (II, 279-390). Lezama insiste en la ortografía Aleijandinhno, de su invención. Increíblemente, ha persuadido a algunos de sus críticos a adoptarla.

${ }^{27}$ Cortázar acude a Lautréamont para comentar a Lezama en una carta (5 agosto 1957) que se reproduce en Recopilación de textos sobre José Lezama Lima, a cargo de Pedro Simón (La Habana: Casa de las Américas, 1970), p. 311). En la misma Recopilación se encuentra un artículo de Cintio Vitier (p. 71), que incluye a Lautréamont en una lista de poetas que lo influyeron. Alvarez Bravo, en su Orbita de Lezama Lima (incluida parcialmente en la Recopilación, p. 47), menciona también a Lautréamont. Ninguno de ellos examina los textos respectivos.

${ }^{28}$ «Después de lo raro, la extrañeza», recogido en Imagen y posibilidad, edición de Ciro Bianchi Ross (La Habana: Letras Cubanas, 1981, p. 164). El editor no parece haber advertido la errata en el nombre del poeta montevideano.

${ }_{29} « \mathrm{E} 1$ secreto de Garcilaso», recogido en Analecta del reloj; ahora en Obras completas, II, pp. 11-43. 
ubicación de Lautréamont con respecto a Góngora: hay en el poeta montevideano un exceso de bravata o de confianza que le hace afirmar que domina su orbe poético, cuando en realidad es arrastrado por él. Véase, por ejemplo, la insensata arrogancia de las Poésies, su testamento.

La otra referencia, del ensayo sobre Julián del Casal en el mismo libro, es mucho más detallada y la transcribo íntegra. Contrastando con la posición de Baudelaire, Lezama definirá así al notorio Conde:

Pero quedaba otra posición no cubierta aún. La que en el siglo XIX desempeñó un Lautréamont: se ha hablado a propósito de éste de dinamogenia primitiva, de acto impuesto como un universo. Ya sabemos que todo acto implica la justa desenvoltura del punto como reducción, un sitio punto donde descargar un golpe brutal. Entre nosotros las fronteras de agua, reducidas, bruñidas, parecen irse reduciendo a un punto terrenal, punto que puede ser demoníaco resorte o una sobresaturada tensión. Ese acto que incluye como el agua, rechaza como el fuego, todavía en nuestra poesía no ha sido presentado. Poesía que más que un acto es una meditación sobre la sustancia, engendrada por el rencor de la especie y por el maligno uno indiviso. Sería tan imprudente su existencia como el provocarla. No se trata de la poesía de los innumerables pequeños absolutos, sino tan sólo esa eternidad aprovechamiento, ese punto como infinito receptor que después se diversifica y ondula. No se trata de un universo poético, cosa poetizada que sería después candorosa reducción. Más allá de la distancia recorrida por la evaporación de la sustancia y más allá de la rumia de la gravitación, todo parece dirigirse, imantarse o provocarse alrededor de una sustancia que suprime toda incoherencia y aun continuidad invisible, pues cualquier fragmento repetiría cualidades mayores no concebidas ni desprendidas, sino eternas participantes impulsadas a su correspondiente progresión y espejo, pero de esta última posición poética, ¿cómo podría hablar yo ahora? (O. C., 97-98) ${ }^{30}$.

El texto original es de 1941, lo que lo hace cuatro años posterior al ensayo de Garcilaso, de 1937. Pero si éste parecía afirmarse en la seguridad del esplendor barroco desde el cual Lezama lee heterodoxamente al poeta de las Eglogas, cuatro años más tarde la visión parece mucho más compleja, hasta el punto de generar esa ilegibilidad que ha estudiado con tanta sutileza Irlemar Chiampi ${ }^{31}$. Porque en la extensa cita anterior se cruzan dos textos, diferentes pero complementarios. El más obvio está centrado en una definición, así sea oblicua y alusiva, del proceso poético de

30 «Julián del Casal», en Analecta del reloj (Obras completas, II, pp. 65-99).

${ }^{31}$ O texto ilegivel (A expressão americana de José Lezama), tesis de Libre docencia, Universidad de São Paulo, 1983, 358 pp. mimeografiadas. 
Lautréamont. A ese texto pertenecen las referencias a la «dinamogenia primitiva», o sea: el acto poético impuesto como un universo, un cosmos; a la «descarga brutal» en un «sitio punto», tan característico del estilo terrorista del joven montevideano; a esas «fronteras de agua» que son inclusivas al tiempo que, como el fuego, rechazan, y que aparecen caracterizadas como «punto que puede ser un demoníaco resorte o una sobresaturada tensión»; a esa poesía engendrada por el «rencor de la especie y por el maligno uno indiviso». Ese aspecto, a la vez líquido y volcánico, de Lautréamont, blasfemo y demoníaco, maldito, define una de las voces de este texto altamente dialógico.

La otra voz corresponde tácitamente al gran poeta católico que es Lezama y que está por ser, también, en un devenir ya definido (con increíble lucidez) con palabras que anticipan el título de su última recopilación póstuma de poesía: Fragmentos a su imán (1977). Rechazando la fácil noción de un «universo poético» que podría ser objeto de una «candorosa reducción», Lezama apunta a una poesía futura que va más allá para «imantarse alrededor de una sustancia que suprime toda incoherencia (...), pues cualquier fragmento repetiría cualidades mayores (...), eternas participantes impulsadas por su correspondiente progresión y espejo». Es decir: una poesía que borrase precisamente la condición de incoherencia y de fragmento que sutilmente imputa Lezama a Lautréamont. Pero en 1941, él ni puede ni quiere ir más adelante en sus especulaciones. Su poesía futura está viva dentro de él, pero no ha sido escrita aún; su sistema poético (que debe mucho también a Paul Claudel) está en formación. Sin embargo, la extraordinaria vislumbre de lo que él llama «última posición poética» le permite definir por alusiones su semejanza y diferencia con Lautréamont.

Pero es sobre todo en su práctica escritural en donde pueden encontrarse deslumbrantes coincidencias con Lautréamont. Sería imposible pretender un relevamiento minucioso de esas afinidades textuales. Al azar de la lectura, y sólo a vía de ejemplo, indicaré un par de casos. Así, en el poema «El cuello», de Fragmentos a su imán, aparece esta cadena de significantes en fuga en que consiste, en buena parte, el sistema metafórico de Lezama y de Lautréamont:

El rocío sobre la uva en la mañana se iguala con la respiración del pájaro, bulto, después cuerpo de niebla, que comienza a respirar ${ }^{32}$.

${ }^{32}$ Fragmentos a su imán (México: Era, 1978), p. 41. 
En un texto de 1959, sobre Emilio Ballagas, es la alusión científica paródica la que enlaza los dos sistemas:

El misterio de la circulación de la linfa, misterio de un círculo que se apresura en el sueño, que gana el tiempo del río, con el movimiento de los ramajes que entintan el streño. Movimiento de la clorofila de los árboles, lenta, rápida, inapresable, pero que allí es la sangre, donde la sangre agotó su expiación (Imagen, p. 37) ${ }^{33}$.

La diferencia, esencial, con Lautréamont es que, como anticipaba el texto crítico de 1941, aquí la incoherencia es sólo aparente y la cualidad de fragmento del texto no impide su imantación. De este modo, Lezama afirma su diferencia con un sistema que indudablemente lo fascinó en la época del doble descubrimiento del surrealismo (en la lectura bretoniana) y de Lautréamont. Pero es sobre todo en la práctica poética de su alter ego José Cemí (que corresponde en la cronología de Paradiso a esos mismos años de descubierta) donde se recogen los mejores ecos de la doble lectura del barroco hispánico y la vanguardia bretoniana. Lo que he llamado en un artículo publicado en esta misma revista "La silogística del sobresalto de Lezama Lima», tiene sus raíces en esta meditación poética de 1941 y en la práctica posterior que atraviesa la obra entera de Lezama como una línea de fuego. Al artículo me remito para mayores elucidaciones ${ }^{34}$. Ahora sólo quiero subrayar esas raíces lejanas pero presentes. La poesía de Lezama es, como toda poesía, sincrónica y no diacrónica; no es de extrañar que en el momento en que descodifica a Góngora y lee apasionadamente a Lautréamont, esté in fieri toda su obra poética posterior, y en particular Paradiso, Oppiano Licario y Fragmentos a su imán.

Como complemento a esta lectura ducassiana de Lezama quisiera apuntar un par de cosas. Si bien Lezama no dedicó, a lo que parece, ningún artículo exclusivo a Lautréamont, publicó en Orígenes (invierno de 1946) un curioso trabajo de Thierry Maulnier, traducido por él mismo del francés, que se titula, en forma algo obvia, «El enigma de Lautréamont» ${ }^{35}$.

${ }^{33}$ «Gritémosle: ¡Emilio!», en Imagen y posibilidad, pp. 36-40.

${ }^{34}$ "Paradiso: Una silogística del sobresalto», en Letras cubanas, número especial de la Revista Iberoamericana, cuya edición preparé (Pittsburgh, julio-diciembre 1975, núms. 92-93, pp. 523-533, 1977). Cuando se publicó ese trabajo no había salido aún Oppiano Licario ni existía la valiosa edición anotada de Paradiso por Eloísa Lezama Lima (Madrid: Cátedra, 1980), obras que contribuyen a elucidar muchos problemas de retórica y poética de la famosa novela. Aún así, no creo que debo rectificar nada de lo escrito en 1975 sobre el tema.

35 «El enigma de Lautréamont», en Orígenes, La Habana, núm. 12, invierno 1946, pp. 37-39. No he podido localizar el texto francés. Es posible que Lezama lo tomase de alguna revista de la época. En un libro tardío de Maulnier, Les vaches sacrées 
Después de resumir los escasos datos biográficos seguros y de citar una autodefinición del poeta («obligo a mi genio a pintar las delicias de la crueldad», etc.), Maulnier indica rápidamente la afinidad con la obra de Rimbaud y define al apócrifo Conde como un «fenómeno de cualquier manera meteórica, algo como la caída de un proyectil celeste cargado de metales y de cristales desconocidos, o como el nacimiento de un volcán (...) en la paz de un paisaje dormido» (p. 37). Esta metafórica descripción puede y debe haber exaltado la imaginación del joven Lezama.

Más adelante, Maulnier señala la posibilidad de situar a Lautréamont en una serie diacrónica cualquiera: «¿Está Lautréamont detrás de su época? ¿Está delante? ¿Está fuera? No puede ser de ninguna época, está definitivamente fuera del tiempo" (ídem). Subraya asimismo el carácter de ritual blasfemo de su obra: «una prodigiosa parada teatral y procesional que le otorga un poderío de religioso maleficio» (p. 38), lo que coincide con la entrelínea de la definición de Lezama de 1941. Contrastándolo con Rimbaud, cuyas raíces en la tribu de los hombres son aún perceptibles, Maulnier presenta a Lautréamont como «armado, lejano, con negra armadura como los caballeros infernales de las leyendas alemanas» (idem), 10 que sugeriría esa descarga de un «golpe brutal» que con semejante imaginería gótica define implícitamente a Lautréamont en el texto de Lezama. También, al referirse indirectamente a las Poésies, Maulnier habla de «la sonrisa de un demoníaco y silencioso escarnio», cuya correspondencia estaría en el «demoníaco resorte» de que habla Lezama en su texto de 1941. El resto del artículo de Maulnier abunda en perspectivas semejantes a las ya glosadas.

Si he insistido en las coincidencias sutiles entre los textos de Lezama y el de Maulnier es porque creo que es significativo que de toda la crítica,

(Paris: Gallimard, 1977, pp. 301-302), hay un resumen del texto traducido por Lezama. Esto hace pensar que nunca recogió el original en libro y que prefirió perpetuarlo sólo en escorzo. Maulnier ha sufrido un eclipse casi total. Por temperamento y gusto, prefería la poesía del Gran Siglo, a la que dedicó una valiosa antología, Poésie du XVII siècle (Paris: La Table Ronde, 1945). Allí observa correctamente que el esfuerzo por definir un arte clásico en Francia tenía raíces nacionalistas; que intentaba liberar a la poesía francesa de las influencias extranjeras; que buscaba sustituir al internacionalismo del barroco -italiano, español, inglés, francés-, «un nouveau style né d'une élaboration purement française» (p. 22). En una antología anterior, Introduction à la poésie française (Paris: Gallimard, 1939), excluye a Lautréamont y a Claudel porque, aunque son constructores de magníficos lenguajes poéticos, no construyen poemas: "Une phrase de Lautréamont ou de Claudel sont assurément poétiques-chargées de poésie, mais non pas autrement que peut l'être une phrase de Chateaubriand ou de Giraudoux» (p. 32). Una vez más, Maulnier certifica su radical clasicismo. Por eso mismo es tan curioso que Lezama lo haya elegido para presentar a Lautréamont a los lectores de Orígenes. 
pequeña pero seminal, sobre Lautréamont de ese período, él haya elegido precisamente este ensayo, soslayando (aparentemente) la edición crítica de los surrealistas, con introducción de André Breton e ilustraciones de Victor Brauner, Max Ernst, Magritte, Matta, Miró, Man Ray e Ives Tanguy, entre otros, y que lleva una abundante selección de juicios (desde el pionero de Léon Bloy, ya citado aquí, hasta los más recientes surrealistas) bajo el título común de «Premières repercussions du Comte de Lautréamont». Del año siguiente es el libro de Gaston Bachelard Lautréamont, como todos los suyos, delirante e iluminador. So pretexto de una lectura "psicoanalítica», Bachelard insiste en el animalismo de Lautréamont, cataloga su bestiario, abunda en el análisis de los actos de violencia y termina por concluir en el descubrimiento de esa «dinamogenia primitiva» a que se había referido precisamente Lezama Lima en texto ya citado. Haber preferido el ensayo (hasta cierto punto elemental) de Thierry Maulnier, a pesar de conocer los de Bachelard y Breton, indica en Lezama una actitud muy particular con respecto a Lautréamont. Su lectura del poeta de Maldoror no quiere ser, ni es, exclusivamente surrealista. En Thierry Maulnier encuentra Lezama esa preocupación por el demonismo, la blasfemia y el escándalo (en el sentido católico de la palabra) que está en la base de su lectura. De esta manera, y sin necesidad de escribir en detalle sobre Lautréamont, introduce en Orígenes (su tribuna poética) una versión ajena del poeta montevideano que coincide en parte con la suya.

\section{LOS TEXTOS SUBYACENTES}

Corresponderá a Severo Sarduy, en un par de luminosos ensayos sobre el barroco y neobarroco, así como en unas Notas sobre Lezama, cerrar este ciclo de alusiones maldorosianas. No es éste el lugar de analizar el primero de estos ensayos, que desde su publicación en 1972 ha sido glosado, citado y hasta plagiado por incontables «especialistas» en la materia ${ }^{36}$. Bastará señalar, para los propósitos de este estudio, que el nombre de Lautréamont no figura en su vasto elenco de referencias. Sin embargo, todo lo que Sarduy dice allí con respecto a la proliferación barroca y la fuga del significante no sólo se aplica al tema de su ensayo, y en particular a Lezama Lima, sino muy específicamente al arte de la comparación, el cómo, tan singular del poeta de Maldoror. Bastaría citar este párrafo:

${ }^{36}$ «El barroco y el neobarroco» está recogido en América Latina en su literatura, edición a cargo de César Fernández Moreno (México: UNESCO/Siglo XXI, 1972, pp. 167-184); «Dispersión/falsas notas» fue escrito especialmente para un «Homenaje a Lezama» que preparé en Mundo Nuevo, Paris, núm. 24, pp. 5-17. 
Otro mecanismo de artificialización del barroco es el que consiste en obliterar el significante de un significado dado pero no reemplazándolo por otro, por distante que éste se encuentre del primero, sino por una cadena de significantes que progresa metonímicamente y que termina circunscribiendo al significante ausente, trazando una órbita alrededor de él, órbita de cuya lectura — que llamaríamos lectura radialpodemos inferirlo (América, p. 170).

Pero es en el ensayo cuatro años anterior sobre Lezama («Dispersión/ Falsas Notas», 1968) donde se ve mejor esta afinidad retórica entre el barroco/neobarroco/Lezama y Lautréamont que he tratado de subrayar en este estudio. Una de las observaciones más penetrantes de ese seminal ensayo de Sarduy es la que se refiere a la naturaleza cultural de la metáfora lezámica:

La démarche lezamesca es, pues, metafórica. Pero la metáfora, el doble devorador de la realidad, desplazador del origen, es siempre y exclusivamente de naturaleza cultural. Como en Góngora, aquí es la cultura quien lee la naturaleza - la realidad - y no a la inversa; es el saber quien codifica y estructura la sucesión desmesurada de los hechos. Lo lingüístico arma con sus materiales un andamiaje, una geometría refleja que define y reemplaza lo no lingüístico (p. 5).

Si en vez de Góngora se escribe Lautréamont, la definición no pierde nada de su precisión retórica. Casi de inmediato, Sarduy abunda en lo que él llama el doblaje, y que corresponde a esa intertextualidad paródica (en el sentido de Bakhtin) que subyace en su pensamiento crítico:

Liberada del lastre verista, de todo ejercicio de realismo -incluyo su peor variante: el realismo mágico-, entregada al demonio de la correspondencia, la metáfora lezamesca llega a un alejamiento tal de sus términos, a una libertad hiperbólica que no alcanza en español - descuento otras lenguas; la nuestra es, por esencia, barroca- más que Góngora. Aquí el distanciamiento entre el significante y el significado, la falla que se abre entre las faces de la metáfora, la amplitud del сомо - de la lengua, puesto que ésta lo implica en todas sus figuras- es máxima. (...) A veces la abertura retórica, la fuerza centrífuga del como es tal, que el acercamiento, la relación entre los términos parece resultar de una autodeterminación del texto: escritura automática o doblaje (Idem, p. 6).

Otra vez, la sustitución de Góngora por Lezama dejaría la cita intacta con una sola rectificación: no es cierto que la lengua española per se sea más barroca que otras. Es la práctica del español, a todos los niveles, lo 
que tolera esta creencia. Pero el francés tiene, además del escándalo de Lautréamont, suficientes ejemplos, en una gama que va de Rabelais a Louis-Ferdinand Céline, para justificar una lectura barroca de su literatura que aún espera el Barthes capaz de deshacer los prejuicios pedagógico-burocráticos que han convertido una lengua viva en la armoniosa momia que celebran tanto las academias cuanto los escritores «revolucionarios» del mundo entero. Pero ésta es otra historia. En el último párrafo de esta cita, Sarduy introduce una alusión al surrealismo («escritura automática») que refuerza el vínculo con Lautréamont. En su propia obra narrativa hay huellas del autor de Maldoror. Sin ánimo exhaustivo, y a vía de ejemplo, quisiera mencionar ahora una, brillante, de Cobra. Consiste, aparentemente, en la descripción de un cuadro muy conocido de Leonor Fini, «Leçon d'anatomie», cuya reproducción se puede ver en el excelente estudio de Constantin Jelenski sobre la autora franco-italiana $(1968)^{37}$. Glosa Sarduy:

En una mesa verde, escueta como un cadalso, la cabeza recostada a una estaca, yacía un joven boquiabierto y desdentado, el abdomen vacío, los ojos hinchados, esférulas que dividían ranuras negras.

Junto al cuerpo tendido, permanecían cuatro niñas igualmente grisáceas y peinadas, cubiertas con enormes pamelas de encaje que puntuaban flores amarillas. Una de ellas había doblado hacia abajo las alas del sombrero — sólo se veía su boca, la otra las había plegado hacia. arriba y mostraba su rostro, altiva.

Más pequeña que las precedentes, una regordeta, que apretaba una gasa azul bordada de escamas, del pellejo que muda una serpiente, bajo su bonete desmesurado, de algas rosadas, abría la boca, el mentón apoyado en una mano abierta, el codo apoyado en el cadáver.

Del sótano subía una niña. No la cubría un sombrero, sino, por supuesto, un paraguas abierto (Cobra, pp. 173-174) ${ }^{38}$.

Inútil buscar algunos detalles de este tableau en el cuadro de Leonor Fini que le sirve de punto de partida. Como los films que narra Molina a su seducible Valentín en El beso de la mujer araña, de Manuel Puig, Sarduy ha contaminado con sus propias invenciones un cuadro algo más calmo y clásico. Bastará señalar que el cadáver no parece de un joven,

${ }^{37}$ Leonor Fini, por Constantin Jelenski (Lausanne: La Guilde du Livre, 1968, p. 153).

${ }^{38}$ Cobra (Buenos Aires: Sudamericana, 1972). En Narradores de esta América (Buenos Aires: Alfa Argentina, 1974) incluyo un trabajo sobre esta novela, «Sarduy: las metamorfosis del texto», pp. 421-443, en donde analizo con detalle sus sistemas: paródico y metafórico. A él remito al lector para mayores elucidaciones. 
sino de un viejo (el desdentado que Sarduy subraya se compadece más con esta hipótesis) y que no hay tal niña subiendo del sótano, con o sin paraguas abierto. Pero es precisamente este detalle, y el por supuesto del áltimo párrafo, lo que permite la revelación del texto subyacente a que alude Sarduy. Es la famosa comparación del canto VI de Maldoror, que Bloy había subrayado, que Darío recoge y que se convierte para Breton en epítome de la imagen surrealista. Lo que lee Sarduy en el cuadro de Leonor Fini es el encuentro fortuito del paraguas sobre la mesa de disección. ¿Y la máquina de coser? Cualquier descodificador de Marcel Duchamp y de sus eróticos molinillos de chocolate sabe que el sexo femenino es, entre otras cosas, una máquina de coser.

Que Sarduy haya intentado esta contaminación doble o triple (Fini, Lautréamont, Duchamp) en el espacio de una sola imagen no ha de extrañar a quienes conozcan su teoría sobre la literatura como intertextualidad paródica, expuesta en el ensayo sobre Lezama, reiterada en el «Barroco y neobarroco», y universalizada en declaraciones recientes que afirman, sin lugar a ninguna posible apelación: toda literatura es paródica ${ }^{39}$. Si Lautréamont hubiera vivido en este siglo, habría encontrado en esta fórmula la justificación de su inaudita empresa. Recapitulo: la presencia visible o tácita del creador de Maldoror en el discurso hispánico sobre el barroco se debe, sobre todo, a que este poeta blasfemo y austral, este desplazado de todas las literaturas, era en la entraña de su texto un poeta barroco cuya ubicación, dentro de una práctica académica francesa y en una lengua que celebra sus limitaciones como triunfos, resultaba totalmente imposible. Pero en el contexto de las letras hispánicas, y gracias a la lectura del Arte de hablar, cuando tenía apenas diecisiete años, el escándalo de Maldoror no resulta tan escandaloso. O, por lo menos, resulta igualmente escandaloso que el de Góngora, Sor Juana, Domínguez Camargo, Lezama Lima o Severo Sarduy. Como la invisible marca de agua que identifica el origen del papel, el barroco sirve para certificar una filiación indeleble entre Lautréamont y los escritores que anticipan, crean y perpetúan la Modernidad del mundo hispánico.

${ }^{39}$ En una entrevista con Julia Kushigian, publicada en Vuelta (México, núm. 89, abril 1984, p. 14), bajo el título de «La serpiente en la Sinagoga», Sarduy afirma: «Ya no hay obra-objeto y obra-paródica, ya no hay lenguaje primero y lenguaje connotativo, ya no hay discurso original y discurso paródico, todo es carnaval, todo es parodia, todo es risa.» Con esta afirmación, el narrador cubano va más lejos que sus maestros Bakhtin y Derrida y que muchos de sus críticos que aún se empeñan en verlo en el contexto provinciano de las letras cubanas. 